\title{
Colonisation by epibionts and meiofauna of real and mimic pneumatophores in a cool temperate mangrove habitat
}

\author{
J. Gwyther ${ }^{1, *}$, P. G. Fairweather ${ }^{2, * *}$ \\ ${ }^{1}$ School of Ecology and Environment, Deakin University, Geelong, Victoria 3217, Australia \\ ${ }^{2}$ School of Ecology and Environment, Deakin University, Warrnambool, Victoria 3280, Australia
}

\begin{abstract}
The size and pace of change in meiofaunal assemblages suggest that meiofauna make excellent subjects for testing theories about how ecological communities change. A field experiment was performed in which the abundance and composition of epibionts and meiofauna on natural, transplanted and mimic pneumatophores were monitored over a 47 wk period. Meiofaunal density increased with growth of algal epibionts, both reaching maximum values after 24 wk, at the end of winter. At this time the assemblages from the 3 substrata were similar, although the combined abundances of meiofauna on transplants and mimics were only $28 \%$ of the average on natural pneumatophores. Meiofaunal abundance on all substrata decreased rapidly during spring as algal cover declined due to desiccation. Twenty-three species of nematode were recorded from mimics compared with 8 and 7 from transplants and pneumatophores, respectively. A temporal sequence of feeding groups occurred in the order of epigrowth feeders, deposit feeders, and omnivore/predators, with the latter 2 adding to rather than replacing earlier trophic groups. Scavengers were found only on natural pneumatophores. The turnover rates of nematode species between all census times were similar, peaking at $63 \%$, but there was no trend in the turnover rates with time. We conclude that mimics are more suitable than transplanted pneumatophores for colonisation studies because of their greater persistence and more easily standardised surface area. Moreover, the composition of colonising assemblages on them closely resembled assemblages on natural pneumatophores at the time of peak meiofaunal abundance.
\end{abstract}

KEY WORDS: Algae $\cdot$ Avicennia marina $\cdot$ Barnacles $\cdot$ Barwon estuary $\cdot$ Copepods $\cdot$ Field experiment Mimic $\cdot$ Nematodes $\cdot$ Succession $\cdot$ Victoria

Resale or republication not permitted without written consent of the publisher

\section{INTRODUCTION}

The meiobenthos has been increasingly recognised as a convenient tool for the study of community dynamics. The life-histories (no pelagic larval phase, generation times of 1 to $2 \mathrm{mo}$ ) and ecology (high abundance and diversity, close association with the substratum, permanent benthic existence, range of trophic

\footnotetext{
*Corresponding author. E-mail: janetg@deakin.edu.au

${ }^{* *}$ Present address: School of Biological Sciences, The Flinders University of South Australia, GPO Box 2100, Adelaide, South Australia 5001, Australia
}

levels) of many meiofaunal taxa render these animals very suitable for studying the effects of pollution and other disturbances (e.g. see Coull \& Chandler 1992 and references therein, Schratzberger et al. 2000). For similar reasons, meiofauna are ideal subjects for the investigation of colonisation and dispersal dynamics in sediments (e.g. Chandler \& Fleeger 1983, Fegley 1988, Atilla \& Fleeger 2000, Zhou 2001). In phytal habitats, several studies have provided data on seasonal changes in meiofauna (Sieburth \& Tootle 1981, Johnson \& Scheibling 1987, Rutledge \& Fleeger 1993, Villano \& Warwick 1995, Jarvis \& Seed 1996, Hull 1997). Meiofauna on decaying mangrove leaf litter were fol- 
lowed over 5 wk by Gee \& Somerfield (1997), who reported significant differences in meiofauna during the process of leaf litter decay. The present study aimed to follow the colonisation of epibionts and meiofauna onto emergent mangrove roots and assess the use of a mimic substratum for further field experiments of meiofaunal community dynamics.

Pneumatophores (vertically projecting peg roots) are prominent features in soft-sediment habitats within mangrove forests of Avicennia marina (Forskål) Vierhapper. These plant structures may grow to $35 \mathrm{~cm}$ in height, extending from shallow lateral roots up to $20 \mathrm{~m}$ from their tree trunk (Gwyther 2000), and are essential to gas exchange in waterlogged soils. A single tree of 2 to $3 \mathrm{~m}$ in height may have 10000 pneumatophores (Hogarth 1999). Studies made in several geographic regions have reported that pneumatophores are encrusted with epibiota, e.g. Sutherland (1980; in Venezuela), Ellison \& Farnsworth (1992), and Farnsworth \& Ellison (1996) (both in Belize), Eston et al. (1992; Brazil), Bayliss (1993; South Australia), Aikanathan \& Sasekumar (1994; Malaysia), Phillips et al. (1996; South Africa) and Catesby \& McKillup (1998; Queensland, Australia). Within the Barwon River estuary, Victoria, southeastern Australia, mangroves occur at the south-westerly limit of their Victorian distribution, and are represented by a single species, A. marina.

The pneumatophores in the Barwon estuary provide discrete islands of hard substratum that support distinctive macro-epibiont and meiofaunal assemblages (Gwyther 2000). Thus, primary space on the pneumatophore may be colonised by the barnacle Elminius modestus or by algae dominated by the rhodophytes Caloglossa spp. and Catenella spp. and the chlorophytes Ulva spp. and Enteromorpha spp. Individual pneumatophores supporting either one or both of these assemblages occur throughout the area, although pneumatophores without any visible fouling are frequent beneath the tree canopy (Gwyther 2000). Each of these 2 macro-epibiont assemblages harbours a distinctive assemblage of meiofauna: halacarid mites dominate barnacle-encrusted pneumatophores, whereas algal epiphytes bear a more even biota of harpacticoid copepods, nematodes and halacarid mites. Both of these assemblages on pneumatophores have been shown (Gwyther 2000) to be significantly different from the meiofaunal assemblage in surrounding sediments (dominated by nematodes).

The distribution of epibiont communities on pneumatophores is patchy at spatial scales from a few centimetres (e.g. adjacent pneumatophores bearing both epibiont types) to several metres (e.g. 2 to 3 m diameter patches of pneumatophores fouled with 1 type of epibiont) (Sutherland 1980, Ellison \& Farnsworth 1992, Bayliss 1993, Farnsworth \& Ellison 1996). Temporal variability is also observed, with increasing cover of algae during winter months in southeastern Australia (Beanland \& Woelkering 1982, 1983, Davey \& Woelkering 1985). The succession of colonisers onto the surface of a bare pneumatophore might be expected to reflect initially the temporal sequence of propagules that find the surface acceptable. Their continuing persistence may then depend on the provision of food, space and shelter from physical stresses as well as the outcomes of various biotic interactions.

The present study aimed to follow the early colonisation of pneumatophores towards the distinctive epibiotic communities described by Gwyther (2000). Suitable substrata for this purpose were assessed by comparing colonisation rates and assemblage composition of meiofauna onto natural but transplanted pneumatophores with those patterns on artificial mimics. The first null hypothesis to be tested was that no differences would be found between the rates of colonisation of algae, barnacles and meiofauna onto transplanted and mimic pneumatophores that were bare at the start of the experiment. The second null hypothesis was that the composition of the assemblages of transplanted, real pneumatophores and mimics would be similar to in situ natural pneumatophores during the experiment. Third, we tested the possibility of predicting abundances of copepods or mites from the percentage cover on natural pneumatophores of algae or barnacles, respectively. The purpose of comparing new mimic pneumatophores with bare, real but dead ones was to assess the suitability of these convenient artificial substrates for further manipulative experiments in mangroves.

\section{MATERIALS AND METHODS}

Study site and sampling. The study site was on the eastern bank of the Barwon River estuary (38 $17^{\prime} \mathrm{S}$, $\left.144^{\circ} 30^{\prime} \mathrm{E}\right)$ in Victoria, southeastern Australia, about $1.5 \mathrm{~km}$ upstream from the river mouth (described by Gwyther 2000). The experiment commenced in April (the austral autumn). Three plots (called jetty, middle and creek) in the midst of dense pneumatophores, each measuring $4 \mathrm{~m}^{2}$ and separated by $5 \mathrm{~m}$, were marked with wooden stakes on the intertidal mudflat. The plots were at equivalent tidal heights (approximately mid-tide level) and spanned the mudflat between 5 and $7 \mathrm{~m}$ seaward of the Avicennia marina trees. Two experimental treatments consisted of wooden mimics versus excised and transplanted, real pneumatophores; controls for these were undisturbed living pneumatophores (hereafter called 'natural') growing within each plot (these 3 treatment types are henceforth collectively referred to as 'units'). 'Mimics' 
were made from untreated wooden (Eucalyptus regnans) dowel rods, measuring $30 \mathrm{~cm}$ in length and $9 \mathrm{~mm}$ in diameter (approximately the average diameter of pneumatophores at the study area: Gwyther unpubl. data). Twenty-four mimics were pushed $15 \mathrm{~cm}$ into the mud in random positions within each plot. 'Transplants' were $30 \mathrm{~cm}$-long living pneumatophores from close to the tree trunks (where epibiota are rare and these aerial roots are longest: Gwyther 2000), clipped at just above mud level. Twenty-four transplants bearing no epibiota were inserted into the mud in each plot. Units of both treatments were placed in random positions within each of the 3 plots, ensuring that no unit contacted another.

The possibility of different temporal trends in the development of epibiota among the test substrata was investigated by following the assemblages for $47 \mathrm{wk}$. Three replicate units of each treatment and control (i.e. 9 units) were removed from each plot at each of 7 time intervals-after 1, 2, 4, 8, 24, 32 and 47 wk from commencement of the experiment on 17 April 1998. The first $8 \mathrm{wk}$ were in the autumn, Weeks 8 to 24 were in winter, Weeks 24 to 32 fell in spring and Weeks 32 to 47 were in summer. At each sample time, the treatment and control units were harvested by clipping off their emergent part just above the sediment level using secateurs. The treatment units were collected separately into plastic bags and returned to the laboratory within $3 \mathrm{~h}$ for fixation in $10 \%$ formalin containing a few drops of Rose Bengal stain per litre. Algal cover of the primary space on each unit was assigned by eye to 1 of 10 percentage classes, from $0-10 \%$ through to 91-100\%.

For processing, each unit was placed into a $100 \mathrm{ml}$ measuring cylinder, shaken vigorously with filtered water and then decanted. The procedure was repeated 10 times for each unit. Washings consisted mostly of meiofauna and algal fragments, and these were filtered through nested 500 and $53 \mu \mathrm{m}$ stainless steel sieves and transferred to a Bogorov counting tray for enumeration of epibiota. The surface of each unit 'mimic' or 'transplant' was also inspected under $50 \times$ magnification for any meiofauna not dislodged during washing. Initial counts of meiofauna distinguished at coarse taxon level (order, class or phylum) were made, and each sample was then transferred to a glass cavity block for slow evaporation to glycerol. Permanent 'ecological mounts' (Somerfield \& Warwick 1996) were made by mounting the sample in fresh glycerol and sealing the coverslip with Bioseal No. 2 (Northern Biological Supplies). The nematode positioned closest to each of 20 randomly chosen grid points on each slide was identified to putative species and/or genus using descriptions by Platt \& Warwick $(1983,1988)$ and Warwick et al. (1998), giving a list of 20 specimens per slide.
Classification of nematodes into 4 feeding groups based on the buccal morphology was first described by Weiser (1953). Group 1 includes species with an unarmed buccal cavity, and Group 2 have mouths armed with 1 or more teeth and/or cuticular ridges, denticles or glands. Groups 1A and 1B include the selective (narrow mouth entrance) and non-selective (wider aperture mouth) deposit feeders that consume bacteria and detritus, respectively. Group 2A has teeth and comprises herbivorous feeders that scrape off algae from the surface of sand grains or pierce single algal cells; Group 2B has wide buccal cavities and glands opening on the teeth, and are omnivore/predators. Although Weiser warned of the over-simplification of this classification, it has been widely used in both its original and modified forms (e.g. Alongi 1990, Jensen 1987, Nicholas et al. 1991). Nematodes in this study, as per Alongi (1990), were grouped into deposit feeders (DF), epigrowth feeders (EG) and omnivore/ predators (O/P). Scavengers ( $\mathrm{S}$, after Jensen 1987), were distinguished as a separate group, as in mangrove nematode studies by Nicholas et al. (1991).

Data analysis. All univariate statistics were carried out using SYSTAT software. Changes in algal or barnacle cover on the 3 substrata (treatments) during the experiment were compared among plot (random factor), week (fixed) and treatment (fixed factor) by 3-way factorial ANOVA. Homogeneity of variance was confirmed by Cochran's test and inspection of residuals. An arcsine transformation of the proportional cover of algae and barnacles on natural pneumatophores normalised these data. Meiofaunal abundances were transformed by taking $\log ($ count +1$)$ and were converted to densities per $10 \mathrm{~cm}^{2}$ for purposes of comparison with meiofaunal studies that use this standard format (see Gwyther 2000 for a justification of this). A 3-way ANOVA determined effects on meiofaunal abundance of plot and treatment across weeks.

The efficacy of wooden rods as artificial pneumatophores for meiofaunal habitat was assessed by multivariate ordination of assemblage characteristics (relative abundance, taxonomic composition) with time. PRIMER software was used for all multivariate tests. Abundance data were standardised and double square-root-transformed prior to construction of BrayCurtis similarity matrices. 10 random starts were run for all MDS ordinations. The assemblages on the 3 substrata up to 32 wk were compared with a 2 -factor crossed ANOSIM test, using 5000 permutations.

The formula given by Smith (1975) was used for calculating species turnover between temporal samples: $T_{\text {ov }}=1 / 2 \times\left(l / n_{j}+g / n_{k}\right) \times 100 \%$ where $l$ is the number of species lost between Censuses $j$ and $k$, and $g$ is the number gained, and $n_{j}$ and $n_{k}$ are the numbers of species in Censuses $j$ and $k$. 


\section{RESULTS}

The wooden dowel rods remained securely in place during the experiment, whereas the surface of the transplanted pneumatophores deteriorated with time. The cortical cells of the transplanted root degraded to a clear, mucilaginous substance consisting of stacks of small disc-shaped gelatinous structures. Eventually, the stele of each pneumatophore remained as a hard stick of only 3 to $5 \mathrm{~mm}$ diameter. The transplanted pneumatophores had deteriorated by Week 32 to such an extent that they could no longer be used in the experiment. Thus, only mimic rods and natural pneumatophores could be harvested after Week 32 .

Although the transplants were on average longer than the mimics, they were slightly thinner (Table 1), such that there was no significant difference between the mean unit surface area of mimic and transplanted pneumatophores. The abundance of epibionts in these 2 treatments was therefore directly comparable. The mean unit surface area of natural pneumatophores was significantly larger than the surface areas of units of the other 2 treatments. Comparisons of faunal abundance were therefore converted to an equivalent unit surface area before comparisons were made.

\section{Algal cover}

Fig. 1A shows that algae colonised no more than 1 to $2 \%$ of the surface area of mimics or transplanted pneumatophores during the first $8 \mathrm{wk}$. There followed a rapid recruitment of algae onto artificial substrates during the winter, to maxima of 100 and $80 \%$ cover of primary space on mimics and transplants, respectively. Maximal cover was reached in spring (at Week 24) followed by a precipitous decline in algal cover on all substrata for the remaining 3 sample times (i.e. over a 6-mo period of warmer seasons). At the last sample collection in Week 47, algal cover on mimic pneumatophores was between 0 and $10 \%($ mean $=6.1 \pm 1.6 \% \mathrm{SE}, \mathrm{n}=9)$. In contrast, algae were absent from the natural pneu-

Table 1. Dimensions of units from the 3 treatments harvested throughout the experiment. Different superscripts indicate significantly different dimensions (Tukey's post hoc comparisons, $\mathrm{p}<0.05$ )

\begin{tabular}{|lcccc|}
\hline $\begin{array}{l}\text { Substratum } \\
\text { type }\end{array}$ & (n) & $\begin{array}{c}\text { Mean } \\
\text { length } \\
\pm 1 \mathrm{SD}(\mathrm{mm})\end{array}$ & $\begin{array}{c}\text { Mean } \\
\text { diameter } \\
\pm 1 \mathrm{SD}(\mathrm{mm})\end{array}$ & $\begin{array}{c}\text { Mean } \\
\text { area } \\
\left(\mathrm{mm}^{2}\right)\end{array}$ \\
\hline Mimic & $(63)$ & $138 \pm 19^{\mathrm{b}}$ & $9.0 \pm 1^{\mathrm{a}}$ & $3903^{\mathrm{b}}$ \\
Transplant & $(54)$ & $167 \pm 40^{\mathrm{b}}$ & $7.5 \pm 1^{\mathrm{a}}$ & $3960^{\mathrm{b}}$ \\
Natural & $(63)$ & $177 \pm 27^{\mathrm{a}}$ & $8.0 \pm 2^{\mathrm{a}}$ & $4450^{\mathrm{a}}$ \\
\hline
\end{tabular}

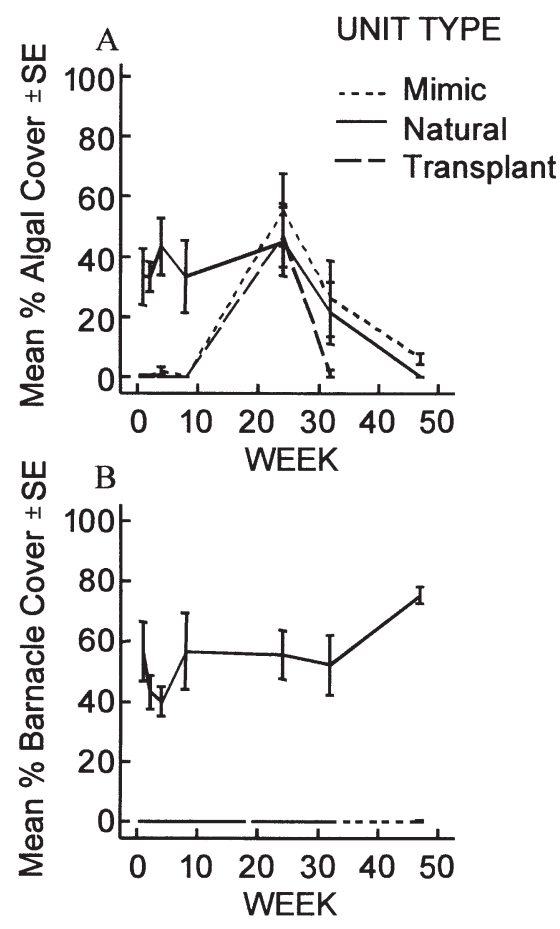

Fig. 1. Percentage cover of algae (A) and barnacles (B) on mimics, 'natural' pneumatophores and transplants between April 1998 and March 1999

matophores by the end of summer. The final samples of transplanted pneumatophores were harvested in Week 32 (December, mid-summer) by which time the mean algal cover was reduced to only $1.1 \pm 1.1 \%(n=9)$.

Algal cover varied interactively among plots and treatments throughout the experiment (Table 2A). Until Week 24, the natural pneumatophores had much more algal cover than either of the other 2 treatments (Fig. 1A), but in Weeks 24 and 32 the type of substratum had no significant effect on algal cover when the 3 substrata were compared by Tukey tests. By Week 47 there was no significant main effect of algal cover on mimics and natural pneumatophores, although algal cover interacted between treatments and plots (Table 2B). At that time the algal cover had declined to zero at the creek site, and only mimics at the jetty and middle plots retained small amounts of algal cover. The composition of algal colonisers and growing epiphytic communities included species of Caloglossa, Catenella, Bostrychia, Enteromorpha and Ulva.

\section{Barnacle cover}

The mean percentage cover of barnacles on all sampled natural pneumatophores between April 1998 and March 1999 (Fig. 1B) was 54.3\% $( \pm 3.0, \mathrm{n}=63)$ and a 
Table 2. (A) 3-way ANOVA of changes in algal cover over Weeks 1 to 32. Factors were plot (random factor), treatment and week (both fixed); data were arcsine-transformed; (B) 2-way ANOVA algal cover at Week 47 only, when treatment $=$ mimics and pneumatophores only. Significant results are in bold

\begin{tabular}{|lrccc|}
\hline Source & df & MS & $F$ & $p$ \\
\hline (A) & & & & \\
Treatment & 2 & 1.24 & $\mathbf{3 1}$ & $\mathbf{< 0 . 0 1}$ \\
Week & 5 & 0.80 & $\mathbf{2 0}$ & $<\mathbf{0 . 0 0 1}$ \\
Plot & 2 & 0.02 & 0.27 & 0.80 \\
Treatment $\times$ Week & 10 & 0.18 & $\mathbf{3 . 0 0}$ & $\mathbf{< 0 . 0 5}$ \\
Treatment $\times$ Plot & 4 & 0.04 & 0.50 & 0.74 \\
Week $\times$ Plot & 10 & 0.04 & 0.48 & 0.90 \\
Treatment $\times$ Week $\times$ Plot & 20 & 0.06 & 0.75 & 0.77 \\
Residual & 108 & 0.08 & & \\
& & & & \\
B) & & & & \\
Treatment & 1 & 0.01681 & 3.9 & $>0.25$ \\
Plot & 2 & 0.00431 & $\mathbf{3 1 . 0}$ & $<\mathbf{0 . 0 0 1}$ \\
Treatment $\times$ Plot & 2 & 0.00431 & $\mathbf{3 1 . 0}$ & $<\mathbf{0 . 0 0 1}$ \\
Residual & 12 & 0.00014 & & \\
\hline
\end{tabular}

2-way ANOVA indicated no significant effect of plot or week on barnacle cover on them. Very few barnacles recruited to mimics or transplants, and so a 3-way ANOVA was not performed. Up to 23 juvenile barnacle recruits (diameter 1 to $2 \mathrm{~mm}$ ) were observed on single natural pneumatophores only in March (Week 47) whilst from 0 up to 9 were counted at this time on single mimics. The transplanted pneumatophores had decayed by this stage of the experiment, so they were not available to barnacle recruits. The experiment was terminated before any further increase in barnacle cover was seen.

\section{Colonisation by meiofauna}

Changes in mean numbers of meiofauna (on 3 replicate units of 3 treatments at 3 sites) from April 1998 to March 1999 are shown in Fig. 2. There was a similar

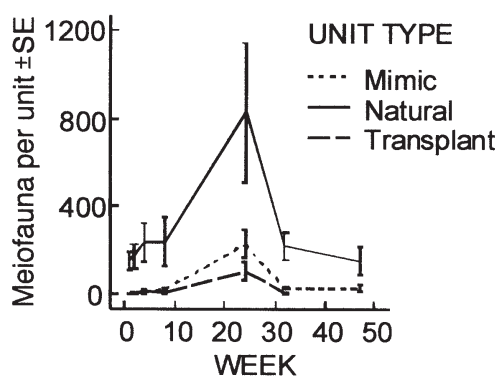

Fig. 2. Abundance of meiofauna on mimics, natural pneumatophores and transplants between April 1998 and March 1999. All taxa included
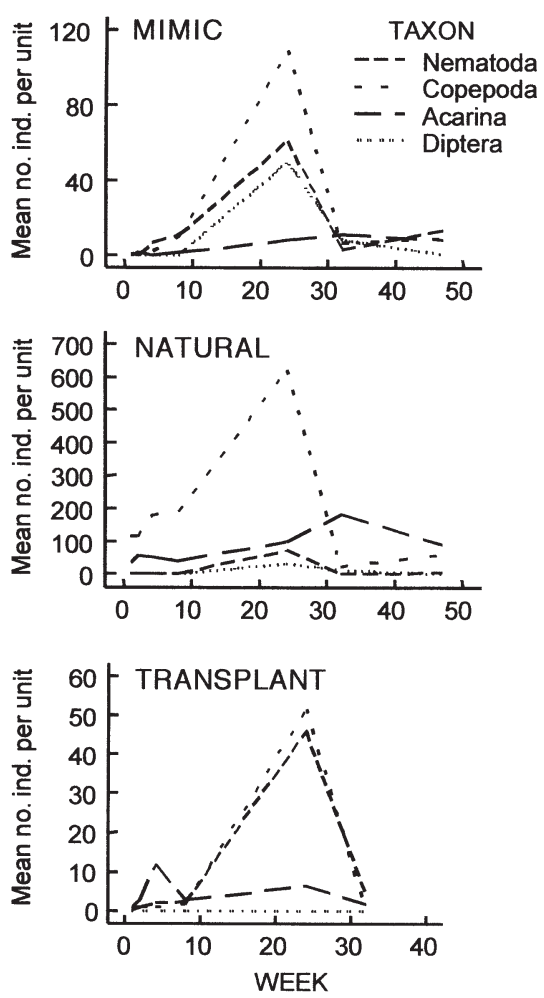

Fig. 3. Mean abundance of the 4 major meiofaunal taxa on single units of each substratum. Note different scales of $y$-axes

temporal pattern of abundance of meiofauna on all the substrata, by which the number of animals built up through the autumn, reached maximum densities for all 3 treatments in Week 24 at the end of winter, and fell back to the low levels of the pre-maxima plateaux by the end of spring. The epibionts on natural pneumatophores supported an abundant assemblage of meiofauna. Although a small number of nematodes contributed to the peak density reached in Week 24, the vast majority of the meiofauna at this time was composed of harpacticoid copepods (Fig. 3).

Although the meiofauna on mimics and transplants followed a similar pattern, abundance was much less than on natural peg roots, but usually somewhat higher on mimics than transplants. This pairwise difference was significant only at Week 24, when the maximal density was reached on all treatments (Table 3 ).

A 3-way ANOVA revealed distinct patterns of significant differences for the main 4 taxa (Table 4). Nematodes only varied over time (Table 4 ), having higher abundances at Week 24 than at other times. For copepods, all 3 main effects were significant (Table 4): again Week 24 exceeded other times; they were more abundant on mimics than transplants (Fig. 3), and plots differed as a random effect. Numbers of the third 
Table 3. Average and maximum abundances (of all meiofaunal taxa combined) on the 3 substrata. Values are expressed as density (number of individuals per unit sampled)

\begin{tabular}{|lccc|}
\hline Treatment & $\begin{array}{c}\text { Mean } \\
( \pm 1 \mathrm{SE}, \mathrm{n}=63) \\
\text { over } 47 \mathrm{wk}\end{array}$ & $\begin{array}{c}\text { Mean } \\
( \pm 1 \mathrm{SE}, \mathrm{n}=9) \\
\text { at Week 24 }\end{array}$ & $\begin{array}{c}\text { Max. on } \\
\text { any unit } \\
\text { at Week 24 }\end{array}$ \\
\hline Mimic & $46 \pm 12.8$ & $229 \pm 60.3$ & 532 \\
Transplant & $23 \pm 7.6^{\text {a }}$ & $104 \pm 34.9$ & 338 \\
Natural & $285 \pm 52.8$ & $828 \pm 285$ & 2610 \\
a Density averaged over only 32 wk for transplants, $\mathrm{n}=54$ \\
\hline
\end{tabular}

numerically dominant taxon, the halacarid mites, were similar at all times except for Week 32, when they were more numerous on pneumatophores than on any other collection date or treatment. This led to significant interactions between all pairs of factors (Table 4). Dipteran larvae showed the most complex result, a significant second-order interaction involving all 3 factors (Table 4), implying that abundance depended on the particular combination of treatment, plot and week. Diptera was the only taxon that showed an overall difference between the 2 experimental unit types (Table 5).

\section{Relationship of meiofaunal abundances to macro- epibiont cover on natural pneumatophores}

Significant but weak correlations between copepods and algal cover and between mites and barnacle cover were found. The abundances of copepods and mites could be predicted from the regression equations for these associations:

$\log$ (no. of copepods) $=0.056(\%$ algal cover $)+1.849$

$$
\left(\mathrm{r}^{2}=0.480 ; \quad F=58.2, \mathrm{df}_{1,61} ; \mathrm{p}<0.001\right)
$$

$\log ($ no. of mites $)=0.021$ (\% barnacle cover $)+2.596$

$$
\left(\mathrm{r}^{2}=0.124 ; F=9.8, \mathrm{df}_{1,61} ; \mathrm{p}=0.003\right)
$$

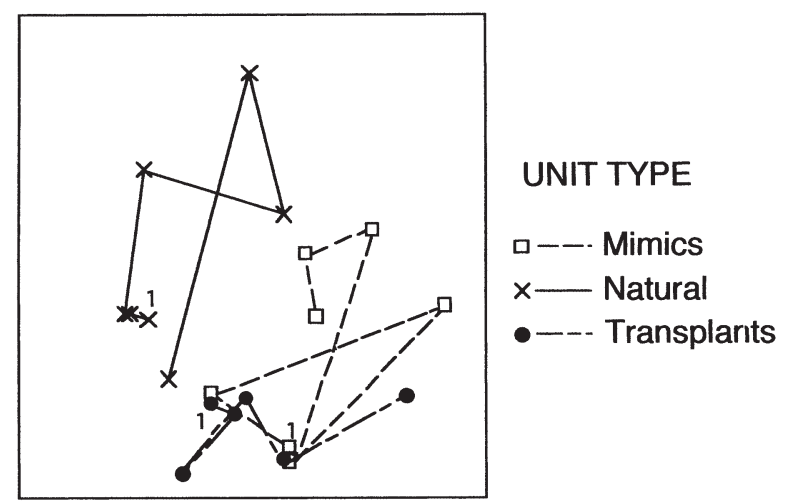

Fig. 4. MDS ordination plot of Bray-Curtis similarities between the meiofaunal assemblages on each substratum at 7 sample times (only 6 for transplanted pneumatophores) averaged across replicates at each time. Stress $=0.15$. Points for each substratum are linked by a line in sequence from the start (=1)

The dominant genera of mites in this mangrove system were the halacarids Isobactrus and Rhombognathus, with a less frequently found unidentified golden oribatid. Copepods were not identified further.

\section{Dowel rods as mimic pneumatophores for meiofaunal assemblages}

Assemblages took rather different trajectories over time (Fig. 4) in the 3 treatments. One-way ANOSIMs done at each sampling time revealed that significant differences existed between assemblages at both 24 and $32 \mathrm{wk}$, but not during the first $8 \mathrm{wk}$ (Table 6). Ordination plots of the meiofaunal taxa at each sampling time (Fig. 5) showed increasingly clustered mimic- and transplant-assemblages at successive times, compared with the consistently more dispersed replicate natural pneumatophores. At the time of peak abundance in Week 24, the meiofaunal assemblage on mimics most closely resembled that on natural pneumatophores

Table 4. Three-way ANOVAs of changes in the logged abundance of the 4 main taxa on mimics and transplanted pneumatophores over $32 \mathrm{wk}$. The factors were treatment and week (both fixed) and plot (random). Results shown in bold are significant at

\begin{tabular}{|c|c|c|c|c|c|c|c|c|c|c|c|c|c|}
\hline \multirow[t]{2}{*}{ Source } & \multirow[t]{2}{*}{ df } & \multicolumn{3}{|c|}{ Nematodes } & \multicolumn{3}{|c|}{ Copepods } & \multicolumn{3}{|c|}{ Mites } & \multicolumn{3}{|c|}{ Dipterans } \\
\hline & & MS & $F$ & $\mathrm{p}$ & MS & $F$ & $\mathrm{p}$ & MS & $F$ & $\mathrm{p}$ & MS & $F$ & $\mathrm{p}$ \\
\hline Treatment & 1 & 1.81 & 1.33 & ns & 7.05 & 45.17 & $*$ & 0.79 & 0.32 & ns & 14.88 & 17.91 & $* * *$ \\
\hline Week & 5 & 14.47 & 12.10 & $* * *$ & 30.15 & 21.94 & $* * *$ & 5.21 & 3.56 & $*$ & 6.19 & $\mathbf{7 . 7 0}$ & ${ }^{* *}$ \\
\hline Plot & 2 & 1.93 & 2.07 & ns & 4.83 & 6.45 & $* * *$ & 0.12 & 0.22 & ns & 0.61 & 1.81 & ns \\
\hline Treatment $\times$ Week & 5 & 1.74 & 2.67 & ns & 1.36 & 1.82 & ns & 3.72 & 4.79 & $*$ & 5.87 & 7.63 & $* *$ \\
\hline Treatment $\times$ Plot & 2 & 1.37 & 1.47 & ns & 0.16 & 0.21 & $\mathrm{~ns}$ & 2.46 & 4.61 & $*$ & 0.83 & 2.48 & ns \\
\hline Week $\times$ Plot & 10 & 1.20 & 1.28 & ns & 1.37 & 1.86 & ns & 1.47 & 2.75 & $*$ & 0.80 & 2.40 & $*$ \\
\hline Treatment $\times$ Week $\times$ Plot & 10 & 0.65 & 0.70 & ns & 0.75 & 1.00 & ns & 0.78 & 1.46 & ns & 0.77 & 2.30 & * \\
\hline Error & 72 & 0.93 & & & 0.75 & & & 0.53 & & & 0.34 & & \\
\hline
\end{tabular}

$$
\alpha=0.05 \text {; ns: not significant }
$$


Table 5. Abundances (mean number per unit $\pm 1 \mathrm{SE}$ ) of the 4 main meiofaunal taxa on mimic and transplanted pneumatophores averaged over all times between April 1998 and March 1999. ${ }^{* * *}$ Dipteran larvae significantly more abundant on mimics ( $p<0.001)$; all other taxa non-significant (Student's $t$-test)

\begin{tabular}{|c|c|c|}
\hline Taxon & $\begin{array}{l}\text { Mimics } \\
(\mathrm{n}=63)\end{array}$ & $\begin{array}{l}\text { Transplants } \\
\quad(\mathrm{n}=54)\end{array}$ \\
\hline Nematodes & $13.7 \pm 4.5$ & $9.4 \pm 6.1$ \\
\hline Copepods & $19.8 \pm 6.7$ & $9.4 \pm 3.8$ \\
\hline Mites & $4.2 \pm 1.1$ & $4.4 \pm 1.3$ \\
\hline Dipteran larvae ${ }^{* * *}$ & $8.4 \pm 3.8$ & $0.02 \pm 0.02$ \\
\hline
\end{tabular}

(Table 6). Differences in abundance of meiofauna for the 3 treatments at Week 24 was tested, and a post hoc comparison revealed similar meiofaunal abundance on mimics and pneumatophores (Table 3). During and following the decline in abundance at Week 32, meiofaunal composition and abundance from all 3 substrata were dissimilar to each other.

\section{Fine taxonomy of nematodes}

Nematodes recorded from the 3 substrata during the experiment are listed in Table 7. Only species of Try-

Table 6. One-way ANOSIM results testing differences of meiofaunal assemblages among 3 substrata at each sampling time; 5000 permutations were run for each comparison. Results in bold are significant at $\alpha=0.05$ (Global R value) or 0.017 (pairwise comparisons with Bonferroni correction)

\begin{tabular}{|c|c|c|c|c|c|c|c|c|c|c|}
\hline \multirow{2}{*}{$\begin{array}{l}\text { ANOSIM or Pair- } \\
\text { wise Comparison }\end{array}$} & \multicolumn{2}{|c|}{ Week 2} & \multicolumn{2}{|c|}{ Week 4} & \multicolumn{2}{|c|}{ Week 8} & \multicolumn{2}{|c|}{ Week 24} & \multicolumn{2}{|c|}{ Week 32} \\
\hline & $\mathrm{R}$ & $\mathrm{p}$ & $\mathrm{R}$ & $p$ & $\mathrm{R}$ & $\mathrm{p}$ & $\mathrm{R}$ & $\mathrm{p}$ & $\mathrm{R}$ & $\mathrm{p}$ \\
\hline Global ANOSIM & 0.10 & 0.06 & 0.06 & $<0.001$ & 0.16 & 0.017 & 0.16 & 0.011 & 0.57 & $<0.001$ \\
\hline Mimic:transplant & -0.06 & 0.68 & 0.12 & 0.11 & 0.04 & 0.27 & 0.25 & 0.013 & 0.51 & 0.001 \\
\hline Mimic:natural & 0.21 & 0.03 & 0.59 & $<0.001$ & 0.32 & 0.004 & 0.11 & 0.11 & 0.48 & $<0.001$ \\
\hline Transplant:natural & 0.15 & 0.04 & 0.38 & 0.001 & 0.12 & 0.09 & 0.17 & 0.02 & 0.77 & $<0.001$ \\
\hline
\end{tabular}

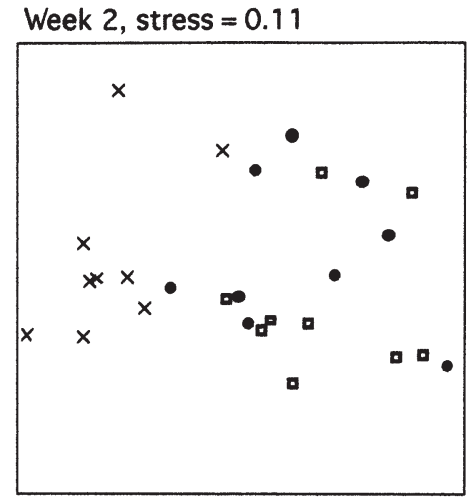

Week 4 , stress $=0.12$

Week 24 , stress $=0.11$

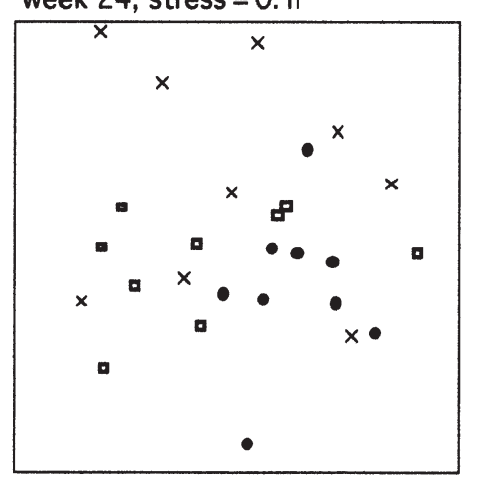

Week 32 , stress $=0.11$

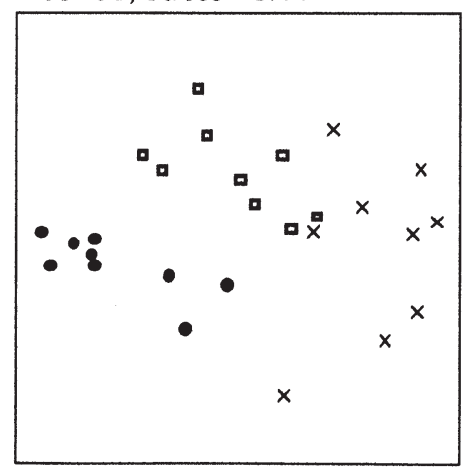

Transplant
Week 8, stress $=0.14$

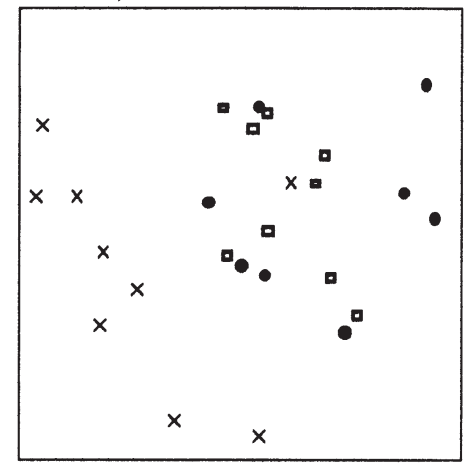

Week 47, stress $=0.10$

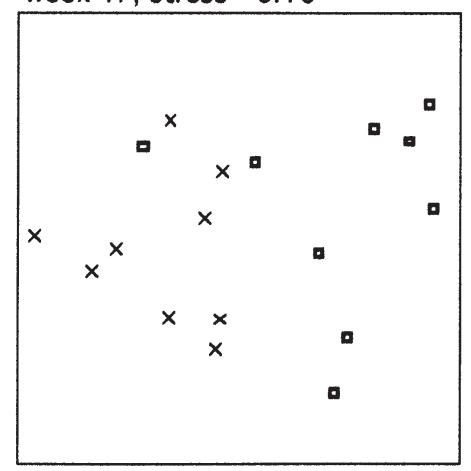

Fig. 5. MDS ordination plots of Bray-Curtis similarities of meiofaunal assemblages on 3 substrata at each sampling time, $\mathrm{n}=27$. NB: no transplants available at Week 47 (see 'Results') 
ploides, Diplolaimella and Metachromadora occurred in all 3 treatments. The family Chromadoridae was represented by 10 genera (out of a total of 26) while the remaining 16 genera represented 12 other families. Species turnover between each pair of times is summarised in Fig. 6. Turnover peaked at $63 \%$ between Weeks 8 and 32, but there was no significant linear or nonlinear trend in turnover rate during the 47 wk period (as assessed by a LOWESS curve).

The greatest number of species was recorded from mimic pneumatophores: of the total 28 species identified from the 3 substrata, 23 ( $82 \%$ ) occurred on mimics compared with only $8(29 \%)$ and $7(25 \%)$ on transplants and natural pneumatophores, respectively. Table 8 indicates a clear sequence of colonisation, which commenced with Chromadorina cf. germanica and C. cf. nudicapitata, recorded on both artificial and transplanted pneumatophores during Weeks 2 and 4 . At 8 wk elapsed time, the number of genera increased from 2 to 17 , but only 5 of these taxa plus 3 additional genera were recorded in the next collection at $24 \mathrm{wk}$. At $32 \mathrm{wk}$ a further 4 genera were pre-
Table 7 . The substrata from which nematode taxa were collected over $47 \mathrm{wk}$ (all times combined). ${ }^{*}$ Species found exclusively on natural pneumatophores. The feeding group of each species according to the buccal structure is also shown, for details see 'Methods'. DF: deposit feeder; EG: epigrowth feeder; O/P: omnivore/predator; S: scavenger; $\times$ : present; -: absent

\begin{tabular}{|lcccc|}
\hline Genus/putative species & $\begin{array}{c}\text { Feeding } \\
\text { group }\end{array}$ & Mimics & $\begin{array}{c}\text { Trans- } \\
\text { plants }\end{array}$ & Natural \\
\hline Adoncholaimus* & O/P & - & - & $\times$ \\
Anoplostoma cf. viviparum & DF & $\times$ & - & - \\
Anticoma & DF & $\times$ & - & - \\
Atrochromadora & DF & $\times$ & - & - \\
Chromadora cf. microlaimus & EG & $\times$ & - & - \\
Chromadorella cf. filiformis & EG & $\times$ & $\times$ & - \\
Chromadorina cf. germanica & EG & $\times$ & $\times$ & - \\
Chromadorina cf. granulopigmentata & EG & $\times$ & - & - \\
Chromadorina cf. nudicapitata & EG & $\times$ & - & - \\
Daptonema & DF & $\times$ & - & - \\
Desmolaimus & DF & $\times$ & - & - \\
Dichromadora & EG & $\times$ & $\times$ & - \\
Diplolaimella & DF & $\times$ & $\times$ & $\times$ \\
Diplolaimelloides & DF & $\times$ & - & - \\
Euchromadora & EG & $\times$ & $\times$ & - \\
Metachromadora cf. remanei & EG & $\times$ & $\times$ & $\times$ \\
Metalinhomoeus & DF & $\times$ & - & - \\
Neochromadora & EG & $\times$ & - & - \\
Onchium* & EG & - & - & $\times$ \\
Paralinhomoeus & DF & - & $\times$ & - \\
Prochromadorella & EG & $\times$ & - & - \\
Ptycholaimellus & EG & $\times$ & - & - \\
Spilophorella & EG & $\times$ & - & - \\
Syringolaimus & O/P & $\times$ & - & - \\
Terschellingia* & DF & - & - & $\times$ \\
Thallassomonhystera & DF & $\times$ & - & - \\
Tripyloides & DF & $\times$ & $\times$ & $\times$ \\
Viscosia* & S & - & - & $\times$ \\
Total taxa & 28 & 23 & 8 & 7 \\
& & & & \\
\hline
\end{tabular}

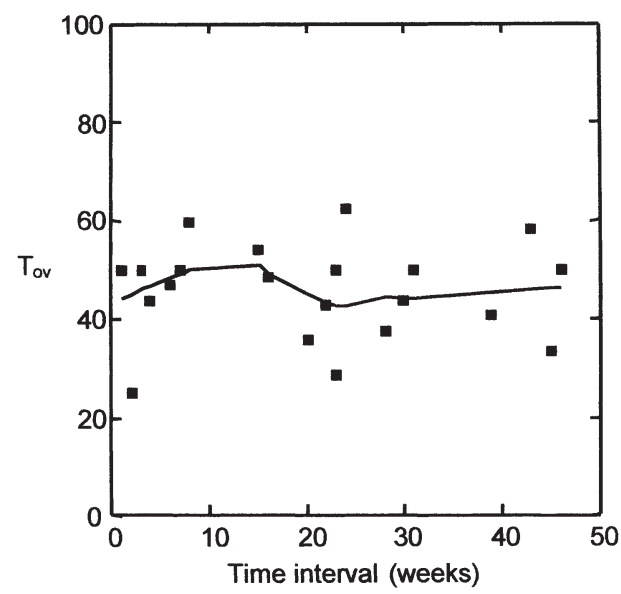

Fig. 6. Percentage turnover $\left(T_{\mathrm{ov}}\right)$ of nematode species between every pair of censuses, mimics and transplants combined. Species turnover was measured as:

$$
T_{\text {ov }}=1 / 2 \times(1 / n j+g / n k) \times 100 \% \quad(\text { Smith 1975) },
$$

where $T_{\mathrm{ov}}=$ percent turnover of species; $l=$ number of species lost between censuses; $g=$ number of species gained between censuses; $n j=$ total number of species present at Census $j_{i}$ $n k=$ total number of species present at Census $k$ sent (but 2 were lost) giving a total of 6 genera ( 8 species). By the final collection date in Week 47, just 3 genera were recorded, and $C$. cf. germanica was numerically dominant in all of these samples, as well as being the only species to be represented at every sampling time.

\section{Feeding groups}

The sequence of 24 nematode species that colonised the mimics and transplants included $54 \%$ epigrowth feeders, $42 \%$ deposit feeders and $4 \%$ omnivore/ predator feeding type (Tables $7 \& 8$ ). The early settlers (up to Week 8) were all epigrowth feeders. Deposit feeders and a predator/omnivore colonised mimics and transplants at Week 8 (Fig. 7) but no scavengers were found on experimental substrata (in contrast with natural pneumatophores) during the trial. Of a total of 7 species recorded from natural pneumatophores, 4 were not found on either of the other treatments. 


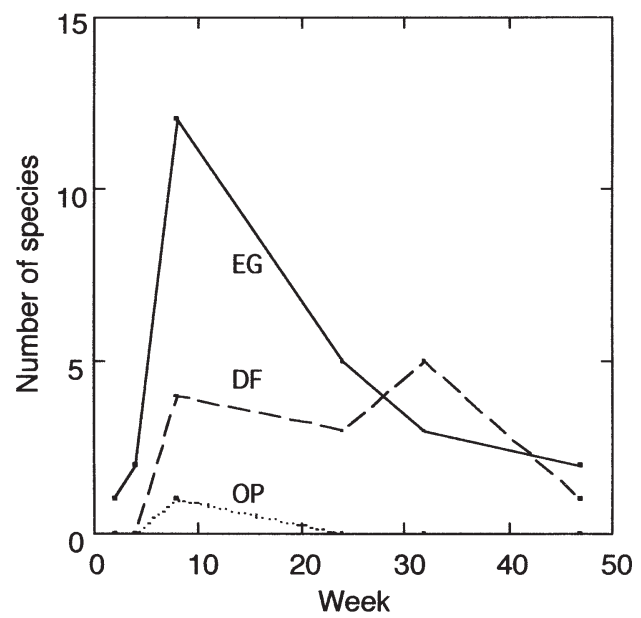

Fig. 7. Number of nematode species in feeding groups during the experiment for mimics and transplants combined. DF: deposit feeders, EG: epistrate grazers, OP: omnivore/predators

\section{DISCUSSION}

Colonisation by algae and meiofauna occurred onto transplanted pneumatophores and mimics made from wooden rods. The reasons for slower colonisation onto excised pneumatophores compared with mimics may involve the protective characteristics of the former's outermost layer. Synthesis of certain phenolic compounds in plant material can be induced by wounding (Matsuki 1996), and so secretion of secondary metabolites due to injury from transplanting may reduce fouling. However, such compounds seem to have little effect in natural pneumatophores, which provide a significant habitat to a variety of epibiota (Gwyther 2000, this study).

The average abundance and the maximal density of meiofauna on mimics was only 28 and $20 \%$, respectively, of those on natural pneumatophores. Slower colonisation rates and lower final abundances of meiofauna in experimental treatments compared with background levels in controls have been reported often in sediment re-colonisation experiments (e.g. Chandler \& Fleeger 1983, Fegley 1988, Zhou 2001). Nematodes were slower colonists than copepods in all these studies. At the time of peak meiofaunal abundance in the present experiment (after $24 \mathrm{wk}$, see Table 6), the composition of assemblages on mimics and natural pneumatophores was similar despite lower total abundance of meiofauna on mimics. The resemblance between the assemblage composition in the 2 treatments also coincided with the time of peak algal cover. Multivariate analyses applied at coarse taxo-

Table 8. Nematodes collected from mimics (M) and transplants (T) at 6 collection times over 47 wk

\begin{tabular}{|c|c|c|c|c|c|c|c|c|c|c|c|}
\hline \multirow[t]{2}{*}{ Taxon } & \multicolumn{2}{|c|}{ Week 2} & \multicolumn{2}{|c|}{ Week 4} & \multicolumn{2}{|c|}{ Week 8} & \multicolumn{2}{|c|}{ Week 24} & \multicolumn{2}{|c|}{ Week 32} & \multirow{2}{*}{$\begin{array}{c}\text { Week } 47 \\
\text { M }\end{array}$} \\
\hline & M & $\mathrm{T}$ & M & $\mathrm{T}$ & M & $\mathrm{T}$ & M & $\mathrm{T}$ & M & $\mathrm{T}$ & \\
\hline Chromadorina cf. germanica & $x$ & $x$ & $x$ & $x$ & $x$ & $x$ & $x$ & $x$ & $x$ & $x$ & $x$ \\
\hline Chromadorina cf. nudicapitata & - & - & $\times$ & $x$ & $\times$ & $\times$ & $x$ & $\times$ & $\times$ & $\times$ & - \\
\hline Tripyloides & - & - & - & - & $x$ & $x$ & $x$ & $x$ & $x$ & $x$ & $x$ \\
\hline Chromadorina cf. granulopigmentata & - & - & - & - & $x$ & - & - & - & $x$ & - & - \\
\hline Dichromadora & - & - & - & - & $\times$ & $\times$ & $x$ & $x$ & - & - & - \\
\hline Metachromadora cf. remanei & - & - & - & - & $\times$ & $\times$ & $x$ & $\times$ & - & - & $\times$ \\
\hline Neochromadora & - & - & - & - & $\times$ & $\times$ & - & - & - & - & - \\
\hline Chromadorina cf. microlaimus. & - & - & - & - & $\times$ & - & - & - & - & - & - \\
\hline Anoplostoma cf. viviparum & - & - & - & - & $x$ & - & - & - & - & - & - \\
\hline Atrochromadora & - & - & - & - & $x$ & $\times$ & - & - & - & - & - \\
\hline Desmolaimus & - & - & - & - & - & $\times$ & - & - & - & - & - \\
\hline Prochromadorella & - & - & - & - & $\times$ & $\times$ & - & - & - & - & - \\
\hline Chromadorina cf. filiformis & - & - & - & - & $x$ & $\times$ & - & - & - & - & - \\
\hline Syringolaimus & - & - & - & - & $\times$ & - & - & - & - & - & - \\
\hline Spilophorella & - & - & - & - & $x$ & - & - & - & - & - & - \\
\hline Ptycholaimellus & - & - & - & - & $\times$ & - & - & - & - & - & - \\
\hline Daptonema & - & - & - & - & $\times$ & - & - & - & - & - & - \\
\hline Thalassomonhystera & - & - & - & - & - & - & $x$ & - & - & - & - \\
\hline Paralinhomoeus & - & - & - & - & - & - & - & $x$ & - & - & - \\
\hline Euchromadora & - & - & - & - & - & - & $x$ & $\times$ & - & - & - \\
\hline Diplolaimella & - & - & - & - & - & - & - & - & $\times$ & $\times$ & - \\
\hline Diplolaimelloides & - & - & - & - & - & - & - & - & $\times$ & - & - \\
\hline Metalinhomoeus & - & - & - & - & - & - & - & - & $\hat{x}$ & - & - \\
\hline Anticoma & - & - & - & - & - & - & - & - & $\times$ & - & - \\
\hline Taxa & 1 & 1 & 2 & 2 & 16 & 10 & 7 & 7 & 8 & 4 & 3 \\
\hline Total taxa per treatment pair & 1 & & & & 1 & 7 & $\varepsilon$ & 8 & 8 & 8 & 3 \\
\hline
\end{tabular}


nomic levels established that the suitability of transplanted, dead pneumatophores as experimental substrata was equivalent to that of mimics until Week 24. However, after this time the meiofaunal assemblages were more similar between mimics and natural pneumatophores than between transplanted and natural pneumatophores (possibly due to transplants degrading). We conclude from these results that mimics were satisfactory substitutes for the pneumatophore habitat because they were colonised by epibiontic algae and barnacles and, furthermore, they supported similarly composed assemblages of meiofauna during the time of peak algal abundance. Advantages in the experimental use of mimics include an easily standardised surface area, as well as greater persistence in the intertidal environment than found for transplanted pneumatophores.

At the level of nematode species (or genus), the mimic pneumatophores supported at least an equal number of taxa as transplants at every sampling time (see Table 8). The species found on mimics but not transplants included all feeding types, and their presence suggests a correspondingly broad range of food resources at least as diverse as that on transplants.

Composition and abundance of meiofauna became increasingly similar up to Week 24, followed by increased dissimilarity that coincided with a major disturbance due to algal decline (Table 6). Further experiments initiated at different seasons in the year are necessary before assertions about cyclical successions can be made. Although meiofauna do not have pelagic propagules, the recruitment of new juveniles may be closely linked to cycles of algal recruitment and growth.

The application to biomonitoring studies of meiofaunal colonisation onto artificial substrata (pot scrubbers, bottle brushes, tiles) was investigated in Louisiana by Atilla \& Fleeger (2000). The surfaces for colonisation were below the water line and, in contrast with the present study, the highest abundances of nematodes and copepods were recorded (in mid-summer) when filamentous microalgae were not present. Their longest study lasted only $8 \mathrm{wk}$, but different copepod species were collected in winter when algae were abundant. However, in the Barwon estuary, pneumatophores are exposed to air at low tide, and bare pneumatophores support extremely limited meiofauna (Gwyther 2000). The greater abundance of meiofauna on unfouled substrata in subtidal positions, reported by Atilla \& Fleeger, emphasises the value of algal epiphytes and barnacles in providing moist microhabitats for meiofauna at intertidal heights. In subtidal regions in northern Japan, Kito (1982) reported that maximum nematode density on Sargassum muticum followed synchronous increases of the standing crop of $S$. muti- cum and the amount of detritus that coated it. The opposite relationships between algae and meiofauna in the latter 2 studies may be due to the differences in habitat complexity that were revealed (Warwick 1977) between filamentous and foliose morphologies, respectively.

A comparison of algal species on mimics with natural epiphytic growth on pneumatophore substrate was not made in the present study but is currently in progress. However, in Westernport Bay (approximately $60 \mathrm{~km}$ east of the Barwon River estuary), Davey \& Woelkering (1985) scraped algae off natural pneumatophores in situ and monitored regrowth over $18 \mathrm{wk}$. The existing assemblage had been dominated by the rhodophytes Catenella nipae, whereas Caloglossa liprieurii prevailed amongst recolonising algae. Seasonal effects were not investigated in their study, which also commenced in the austral autumn.

The marked decline in epiphytic algae throughout late spring and summer coincided with the onset of hot sunny weather. Algae became bleached following daylight low tides from October onwards, and did not recover from these events until after the study had terminated (March). Such seasonal effects are very pronounced within this temperate system. Although the mean daily maximum temperature is 20 to $23^{\circ} \mathrm{C}$ in summer there are on average, $14 \mathrm{~d}$ that attain over $30^{\circ} \mathrm{C}$, and $2 \mathrm{~d}$ that attain over $40^{\circ} \mathrm{C}$ each year (data averaged over $21 \mathrm{yr}$, supplied by the Bureau of Meteorology (2000, available at: www.bom.gov.au/climate/average). Summer low tides during the middle of the day expose intertidal algae to extreme desiccation. Summer rainfall is low in this region, increasing from a mean monthly average of about $40 \mathrm{~mm}$ during December to February to about $67 \mathrm{~mm}$ over July to September. The greatest abundance of algae and meiofauna on pneumatophores was in September (early spring), which coincided with the beginning of rising daily temperatures but followed peak rainfall. Monthly average air temperature increases and rainfall decreases from September through to March, at the time of declining abundance of both epiphytic algae and meiofauna on pneumatophores. In contrast with the present findings in temperate mangroves, Eston et al. (1992) found colonisation of artificial and natural mangrove substrata in warm-temperate Brazil (Latitude $28^{\circ} 30^{\prime} \mathrm{S}$ ) to occur most rapidly in summer, when the most abundant algal genus (Bostrychia) settled to form a monotypic cover. Those authors found an increase in algal biomass from the seaward to landward sectors of the mangroves, whereas the opposite trend was found in temperate Westernport Bay by Davey \& Woelkering (1985).

The spring decline in algal cover was mirrored by a decline in meiofaunal abundance. Even at the small spatial scale of meiofauna, a bare pneumatophore 
seems devoid of suitable habitat; a previous study (Gwyther 2000) found that a few mites were the sole meiofauna on unfouled pneumatophores. Bartsch (1989) recorded mites among barnacles and algae in several geographical regions, but she considered mites to be very rare in silty flats. At our study site, mites made up only $0.2 \%$ of sediment meiofauna but represented $91 \%$ of the meiofauna on barnacle-covered pneumatophores (Gwyther 2000). Mites showed an increase in numbers on pneumatophores as the algal cover waned, whereas the abundances of all other taxa declined (see Fig. 3). The majority of mites on pneumatophores belonged to the sub-family Rhombognathidae, whose members, unlike other halacarids, are algivorous and numerically dominant in most intertidal habitats (Bartsch 1979). Pneumatophores are clearly valuable in providing patches of suitable habitat for mites in an otherwise muddy system. A study of the trophic link between microalgae of surface biofilms and phytophagous mite populations is needed to confirm the value of pneumatophores as a resource of both habitat and food.

The colonisation results showed that peak abundances of copepods and mites were asynchronous (Fig. 3), and this temporal separation of the 2 dominant taxa on natural pneumatophores suggests the possibility of these peaks representing seres of a successional process. Although the species of copepods and mites were not distinguished, the sequence of nematode species that colonised mimic and transplanted pneumatophores revealed changes in both richness and feeding types during the experiment. Whereas the earliest colonists (at $2 \mathrm{wk}$ ) were represented by 2 congeneric species, richness of the assemblage had increased to 17 species (14 new genera) by $8 \mathrm{wk}$. Only 5 of these persisted in the assemblage at $6 \mathrm{mo}$, and just 3 remained at the conclusion of the experiment. In Malaysia, Gee \& Somerfield (1997) reported a successional sequence of nematodes that colonised leaf litter during the decay process, but the copepod fauna was more or less fully developed by the second week that leaves were on the mud-flat. In Louisiana, Atilla \& Fleeger (2000) found 11 copepod species upon artificial substrates at $2 \mathrm{wk}$, but this fell to 8 species by $8 \mathrm{wk}$. Monitoring the substrates used in their study over a longer term may have revealed the persistence of some copepod species. Their initially rich assemblage probably reflected the active dispersal behaviour of copepods compared with the weak swimming ability, and thus passive dispersal, of most nematodes.

A recent experiment (Zhou 2001) showed that sediment-colonising nematodes in a sub-tropical mangrove were more dominated by deposit feeders in detritus-enriched sediment than in ambient controls. In the Barwon mangroves, epigrowth feeders were the pioneer trophic assemblage on mimic pneumatophores, but subsequent colonisers included additional trophic groups. These findings suggest that pioneer species are not restricted to any trophic group but rather represent the group best able to exploit the resources available.

The most common feeding type within nematodes from all 3 substrata was the epigrowth feeders, which have a buccal cavity adapted to graze plant cells by piercing them and sucking out the contents. This trophic group was well represented by the family Chromadoridae, in common with nematode assemblages from Sargassum muticum reported by Kito (1982). Chromadorina cf. germanica was the only .species present at each sampling time. This species was not abundant in mud, and was not recorded from natural pneumatophores, but is present (Gwyther unpubl. data) on decaying leaves that are subject to all stages of fouling as they deteriorate, from the initial biofilm through to tufts of filamentous algae and trapped detritus. These data suggest that $C$. cf. germanica utilises biofilms as well as more aged phytal surfaces. The wide range of phytal habitats of chromadorids in temperate, northern-hemisphere brackish seas (Jensen 1984) includes all types of submerged vegetation. In the winter, when the phytal material breaks down and is incorporated as detritus into the sediment, the chromadorids remained in the sediment. They emerged in spring to recolonise newly growing macrophytes (Jensen 1984). This strategy contrasts with that of the monhysterids Diplolaimella spp. and Diplolaimelloides spp., which were only recorded in the present study following the peak algal growth phase on experimental units. These 2 genera are known to be associated with the process of macrophyte decomposition (Villano \& Warwick 1995), and their presence on mimics (and transplants for Diplolaimella) in Week 32 suggests a role in decomposition processes by grazing on the bacterial fauna.

Of 4 nematode genera found exclusively on natural pneumatophores (Table 7), 3 were more suited to ingest detritus or to prey on other meiofauna than to consume diatom cells of the early biofilm. These were Viscosia (scavenger), Terschellingia (deposit feeder) and Adoncholaimus (omnivore/predator). The fourth genus only found on natural pneumatophores was Onchium, an epigrowth grazer with a piercing stylet. The absence of these genera from experimental substrata could be interpreted as immaturity of the latter assemblages, even after $47 \mathrm{wk}$. The more complex habitat structure of foliose algae and trapped detritus that covers natural pneumatophores would be expected to provide additional niches for nematodes (and other phyla), and these may only develop over a longer period of time. 
The greatest species richness (17 species) was recorded at 2 mo but, of these species, only 5 persisted for 6 further months. These data suggest a dynamic assemblage, and the turnover of nematode species from experimental substrata was great, peaking at $63 \%$ over a period of $24 \mathrm{wk}$. Most nematodes are not active swimmers, and some species collected from the experimental surfaces may have been only transient individuals alighting on a surface that presented suitable stimuli for colonisation. It is not known whether the resources available on mimics or transplanted pneumatophores were sufficient to sustain the species found there, and further experiments are needed to investigate trophic and reproductive relations. The sequence of species of certain feeding types can be interpreted as succession, although the possibility of more ephemeral occupation cannot be discounted.

In conclusion, manipulation of substrata for meiofaunal assemblages provides a convenient tool for further study into marine succession, and invites an experimental approach into both the temporal and spatial dimensions of changing communities.

Acknowledgements. We would like to acknowledge technical help and facilities provided by Rod Watson and the Queenscliff Marine Station during parts of this study. Dr John G. Aberton made helpful comments on the manuscript and assisted with fieldwork. We acknowledge the comments of 3 anonymous reviewers which improved the manuscript. This study forms part of a candidature for the degree of $\mathrm{PhD}$ by the first author, within the School of Ecology \& Environment, Deakin University, Australia.

\section{LITERATURE CITED}

Aikanathan S, Sasekumar A (1994) The community structure of macroalgae in a low shore mangrove forest in Selangor, Malaysia. Hydrobiologia 285:131-137

Alongi DM (1990) Intertidal zonation and seasonality of meiobenthos in tropical mangrove estuaries. Mar Biol 95: $447-458$

Atilla N, Fleeger JW (2000) Meiofaunal colonisation of artificial substrates in an estuarine embayment. PSZN I: Mar Ecol 21:69-83

Bartsch I (1979) Five new species of Halacaridae from New Zealand. N Z J Mar Freshw Res 13:175-185

Bartsch I (1989) Marine mites: a geographical and ecological survey. Hydrobiologia 178:21-42

Bayliss DE (1993) Spatial distribution of Balanus amphitrite and Elminius adelaidae on mangrove pneumatophores. Mar Biol 116:251-256

Beanland WR, Woelkering WJ (1982) Studies on Australian mangrove algae. II. Composition and geographic distribution of communities in Spencer Gulf, South Australia. Proc R Soc Vic 94:89-106

Beanland WR, Woelkering WJ (1983) Avicennia canopy effects on mangrove algal communities in Spencer Gulf, South Australia. Aquat Bot 17:309-313

Catesby S, McKillup S (1998) The importance of crevices to the intertidal snail Littoraria articulata (Philippi) in a tropical mangrove forest. Hydrobiologia 367:131-138
Chandler GT, Fleeger JW (1983) Meiofaunal colonisation of azoic estuarine sediment in Louisiana: mechanisms of dispersal. J Exp Mar Biol Ecol 69:175-188

Coull BC, Chandler T (1992) Pollution and meiofauna: field, laboratory and mesocosm studies. Oceanogr Mar Biol Annu Rev 30:191-271

Davey A, Woelkering WJ (1985) Studies on Australian mangrove algae. III. Victorian communities: structure and recolonization in Westernport Bay. J Exp Mar Biol Ecol 85:177-190

Ellison AM, Farnsworth EJ (1992) The ecology of Belizean mangrove-root fouling communities: patterns of epibiont distribution and abundance, and effects on growth. Hydrobiologia 247:87-98

Eston VR, Rosario A, Braga M, Cordiero-Marino M, Fujii MT, Yokoya NS (1992) Macroalgal colonization patterns on artificial substrates inside southeastern Brazilian mangroves. Aquat Bot 42:315-325

Farnsworth EJ, Ellison AM (1996) Scale dependent spatial and temporal variability in biogeography of mangrove root epibiont communities. Ecol Monogr 66:45-66

Fegley SR (1988) A comparison of meiofaunal settlement onto the sediment surface and recolonisation of defaunated sandy sediment. J Exp Mar Biol Ecol 123:97-113

Gee MJ, Somerfield PJ (1997) Do mangrove diversity and leaf litter decay promote meiofaunal diversity? J Exp Mar Biol Ecol 218:13-33

Gwyther J (2000) Meiofauna in phytal-based and sedimentary habitats of a temperate mangrove ecosystem-a preliminary survey. Proc R Soc Vic 112:137-151

Hogarth PJ (1999) The biology of mangroves. Oxford University Press, New York

Hull SL (1997) Seasonal changes in diversity and abundance of ostracods on four species of intertidal algae with differing structural complexity. Mar Ecol Prog Ser 161:71-82

Jarvis SC, Seed R (1996) The meiofauna of Ascophyllum nodosum - characteristics of assemblages associated with 2 common epiphytes. J Exp Mar Biol Ecol 199:249-267

Jensen P (1984) Ecology of benthic and epiphytic nematodes in brackish waters. Hydrobiologia 108:201-217

Jensen P (1987) Feeding ecology of free-living aquatic nematodes. Mar Ecol Prog Ser 35:187-196

Johnson SC, Scheibling RE (1987) Structure and dynamics of epifaunal assemblages on intertidal macroalgae Ascophyllum nodosum and Fucus vesiculosus in Nova Scotia, Canada. Mar Ecol Prog Ser 37:209-227

Kito K (1982) Phytal marine nematode assemblage on Sargassum muticum Agardh. with reference to the structure and seasonal fluctuations. J Fac Sci Hokkaido Univ Ser VI Zool 23:143-161

Matsuki M (1996) Regulation of plant phenolic synthesis: from biochemistry to ecology and evolution. Aust J Bot 44: 613-634

Nicholas WL, Elek JA, Stewart AC, Marples TG (1991) The nematode fauna of a temperate Australian mangrove mudflat-its population density, diversity and distribution. Hydrobiologia 209:13-28

Phillips A, Lambert G, Granger JE, Steinke TD (1996) Vertical zonation of epiphytic algae associated with Avicennia marina (Forssk.) Vierh. pneumatophores at Beachwood Mangroves Nature Reserve, Durban, South Africa. Bot Mar 39:167-175

Platt HM, Warwick RM (1983) Freeliving marine nematodes. Part I. British enoplids. In: Kermac DM, Barnes RSK (eds) Synopsis of the British fauna (New Ser.) No. 28. Cambridge University Press, Cambridge, UK

Platt HM, Warwick RM (1988) Freeliving marine nematodes. 
Part II. British chromadorids. In: Kermac DM, Barnes RSK (eds) Synopsis of the British fauna (New Ser.) No. 38. Cambridge University Press, Cambridge, UK

Rutledge PA, Fleeger JW (1993) Abundance and seasonality of meiofauna, including harpacticoid copepod species, associated with stems of the salt-marsh cord grass, Spartina alterniflora. Estuaries 16:760-768

Schratzberger M, Rees HL, Boyd SE (2000) Effects of simulated deposition of dredged material on structure of nematode assemblages - the role of contamination. Mar Biol 137:613-622

Sieburth J, Tootle JL (1981) Seasonality of microbial fouling in Ascophyllum nodosum (L.) Le Jol., Fucus vesiculosus L, Polysiphonia lanosa (L.) Tandy and Chondrus crispus Stackh. J Phycol 17:57-64

Smith CL (1975) Analysis of a coral-reef fish community: sizes and relative abundance. Hydro-Lab J 3:31-38

Somerfield PJ, Warwick RM (1996) Meiofauna in marine monitoring programmes: a laboratory manual. Ministry of Agriculture, Fisheries and Food, Directorate of Fisheries Research, Lowestoft

Editorial responsibility: John Gray (Contributing Editor), Oslo, Norway
Sutherland JP (1980) Dynamics of the epibenthic community on roots of the mangrove Rhizophora mangle, at Bahía de Buche, Venezuela. Mar Biol 58:75-84

Villano N, Warwick RM (1995) Meiobenthic communities associated with the seasonal cycle of growth and decay of Ulva rigida Agardh in the Palude Della Rosa, Lagoon of Venice. Estuar Coast Shelf Sci 41:181-194

Warwick RM (ed) (1977) The structure and seasonal fluctuations of phytal marine nematode associations on the Isles of Scilly. Pergamon Press, New York

Warwick RM, Platt HM, Somerfield PJ (1998) Free-living marine nematodes. Part III. Monhysterids. In: Kermac DM, Barnes RSK (eds) Synopsis of the British fauna (New Ser.) No. 53. Cambridge University Press, Cambridge, UK

Weiser W (1953) Die Beziehung zwischen Mundhöhlengestalt, Ernährungsweise und Vorkommen bei freilebenden marinen Nematoden. Ark Zool 4:439-484

Zhou H (2001) Effects of leaf litter addition on meiofaunal colonisation of azoic sediments in a sub-tropical mangrove in Hong Kong. J Exp Mar Biol Ecol 256:99-121

Submitted: April 3, 2001; Accepted: July 26, 2001

Proofs received from author(s): February 20, 2002 